Jurnal Pendidikan; Vol. 7, No. 1, Januari 2019

p-ISSN: 2337-7607; e-ISSN : 2337-7593

\title{
Meningkatan Hasil Belajar Matematika Melalui Model Pembelajaran Cooperative Learning Tipe STAD dengan Pendekatan Scientific Pada Siswa Kelas X Akutansi SMK Muhammadiyah Aimas
}

\author{
Surya Putra Raharja \\ STKIP Muhammadiyah Sorong
}

\begin{abstract}
This research is a Classroom Action Research which aims to improve mathematics learning outcomes through the STAD Cooperative Learning Type Learning Model with a Scientific Approach to Class X Accounting Students of Muhammadiyah Aimas Vocational School. The subject of this study was Accounting students at Muhammadiyah Aimas Vocational School with a total of 15 students. The research was conducted in the odd semester of the 2018/2019 academic year. This study uses the Cooperative Learning Type STAD learning model with the Scientific Approach. This research was conducted in two cycles, the first cycle was carried out four times the learning activities carried out with the first cycle test, as well as the second cycle carried out 4 times learning activities followed by cycle II tests. The results of the first cycle and second cycle test were analyzed quantitatively and the student observation data were analyzed qualitatively. The results of this study indicate that the learning outcomes of mathematics in class X of Muhammadiyah Aimas Vocational School in the first cycle obtained an average of 59.44. In the second cycle obtained an average score of 85.17 and a standard deviation of 11.00 with an ideal score of 100. Based on the results of this study, conclusions can be drawn on the application of learning using Cooperative Learning Type STAD with the Scientific Approach can improve learning outcomes of class X SMK Muhammadiyah Aimas the indicator is an increase in the average score of mathematics learning outcomes of students from the low category in the first cycle of 59.44 to 85.17 in the second cycle which is in the high category.
\end{abstract}

Keywords: mathematics, scientific, learning outcomes

\begin{abstract}
Abstrak: Penelitian ini adalah penelitian tindakan kelas (Classroom Action Reseach) yang bertujuan untuk meningkatkan hasil belajar matematika melalui Model Pembelajaran Cooperative Learning Tipe STAD dengan Pendekatan Scientific Pada Siswa Kelas X Akutansi SMK Muhammadiyah Aimas. Subjek penelitian ini adalah siswa kelas Akutansi SMK Muhammadiyah Aimas dengan jumlah siswa 15. Penelitian ini dilaksanakan pada semester ganjil tahun ajaran 2018/2019. Penelitian ini menggunakan model pembelajaran Cooperatve Learning Tipe STAD dengan Pendekatan Scientific. Penelitian ini dilakukan sebanyak dua siklus, siklus I dilaksanakan 4 kali kegiatan pembelajaran yang dilangsungkan dengan tes siklus I, demikian juga siklus ke II dilaksanakan 4 kali kegiatan pembelajaran yang dilanjutkan dengan tes siklus II. Hasil tes siklus I dan siklus II dianalisis secara kuantitatif dan data hasil observasi siswa dianalisis secara kualitatif. Hasil penelitian ini menunjukkan bahwa hasil belajar matematika kelas X SMK Muhammadiyah Aimas pada siklus I diperoleh rata-rata 59.44. Pada siklus II diperoleh skor ratarata 85,17 dan standar deviasi 11.00 dengan skor ideal 100. Berdasarkan hasil penelitian ini maka dapat ditarik kesimpulan penerapan pembelajaran dengan menggunakan pembelajaran Cooperatve Learning Tipe STAD dengan Pendekatan Scientific dapat meningkatkan hasil belajar siswa kelas X SMK Muhammadiyah Aimas yang indikatornya berupa peningkatan skor rata-rata hasil belajar matematika siswa dari kategori rendah pada siklus I sebesar 59,44 menjadi 85,17 pada siklus II yang berada pada kategori tinggi
\end{abstract}

Kata Kunci: matematika, scientific, hasil belajar 
Jurnal Pendidikan; Vol. 7, No. 1, Januari 2019

p-ISSN: 2337-7607; e-ISSN : 2337-7593

\section{Pendahuluan}

Pembelajaran merupakan proses ilmiah. Karena itu Kurikulum 2013 mengamanatkan esensi pendekatan ilmiah dalam pembelajaran. Pendekatanscientificatau ilmiah diyakini sebagai titian emas perkembangan dan pengembangan sikap, keterampilan, dan pengetahuan peserta didik. Dalam pendekatan atau proses kerja yang memenuhi kriteria ilmiah, para ilmuwan lebih mengedepankan pelararan induktif (inductive reasoning) ketimbang penalaran deduktif (deductive reasoning). Penalaran deduktif melihat fenomena umum untuk kemudian menarik simpulan yang spesifik.Sebaliknya, penalaran induktif memandang fenomena atau situasi spesifik untuk kemudian menarik simpulan secara keseluruhan.Sejatinya, penalaran induktif menempatkan bukti-bukti spesifik ke dalam relasi idea yang lebih luas. Metode ilmiah umumnya menempatkan fenomena unik dengan kajian spesifik dan detail untuk kemudian merumuskan simpulan umum. Guna meningkatkan partisipasi dan keaktifan siswa dalam kelas, peneliti mencoba menerapkan model pembelajaran kooperatif tipe $S T A D$. Tipe make a match atau mencari pasangan merupakan salah satu alternatif yang dapat diterapkan kepada siswa. Model pembelajaran kooperatif tipe Student TeamsAchievement Divisions (STAD) dengan pendekatan Scientificakan menciptakan suasana belajar dimana siswa bekerja secara berkelompok sehingga pembelajaran akan berorientasi kepada siswa dan siswa dapat memperoleh pengetahuannya dengan baik.

Berdasarkan uraian di atas, peneliti tertarik untuk melakukan penelitian yang berjudul "Peningkatan Hasil Belajar Matematika Melalui Model Pembelajaran Cooperative Learning Tipe STAD dengan Pendekatan Scientific Pada Siswa Kelas X Akutansi SMK Muhammadiyah Aimas".

\section{Metode Penelitian}

\subsection{Desain Penelitian}

Penelitian ini adalah penelitian tindakan kelas (Class Room Action Receach) yang terdiri dari beberapa tahap yaitu perencanaan, pelaksanaan tindakan, observasi/evaluasi dan refleksi.

\subsection{Tempat dan Waktu Penelitian}

Penelitian ini dilaksankan di kelas X SMK Muhammadiyah Aimas dengan jumlah 41 Siswa. Sedangkan Subjek penelitian ini adalah siswa kelas Akutansi SMK Muhammadiyah Aimas dengan jumlah siswa 15. Penelitian ini dilaksanakan pada semester ganjil tahun ajaran 2018/2019.

\subsection{Desain Penelitian}

Penelitian ini adalah penelitian tindakan kelas (Class Room Action Receach) yang terdiri dari beberapa tahap yaitu perencanaan, pelaksanaan tindakan, observasi/evaluasi dan refleksi. Desain Penelitian

Penelitian ini adalah penelitian tindakan kelas (Class Room Action Receach) yang terdiri dari beberapa tahap yaitu perencanaan, pelaksanaan tindakan, observasi/evaluasi dan refleksi.

\subsection{Tempat dan Waktu Penelitian}

Penelitian ini dilaksankan di kelas X SMK Muhammadiyah Aimas dengan jumlah 41 Siswa. Sedangkan Subjek penelitian ini adalah siswa kelas Akutansi SMK Muhammadiyah Aimas dengan jumlah siswa 15. Penelitian ini dilaksanakan pada semester ganjil tahun ajaran 2018/2019.

\subsection{Teknik Pengumpulan Data}

Teknik pengumpulan data yang dilakukan oleh penulis dalam penelitian ini adalah sebagai berikut:

1. Sumber data: Siswa Kelas X Akutansi SMK Muhammadiyah Sorong yang mengikuti pembelajaran Cooperative Learning Tipe STAD dengan Pendekatan Scientific.

2. Cara pengambilan data meliputi:

a. Data mengenai kehadiran, dan keaktifan siswa yang diperoleh dari lembar observasi 
b. Data mengenai hasil belajar siswa yang diperoleh dari tes pada setiap akhir siklus dalam bentuk ulangan harian.

\subsection{Teknik Analisis Data}

Data yang terkumpul dianalisis dengan cara kuantitatif dan kualitatif. Untuk data tentang hasil tes dianalisis secara kuantitatif dengan menggunakan statistik deskriptif yaitu dengan menghitung rata-rata (mean), rentang, Modus, nilai maksimum dan minimum serta standar deviasi yang diperoleh siswa pada setiap bahasan pelajaran. Kemudian nilai tersebut dikategorikan kedalam lima kategori dengan menggunakan Kategorisasi Skala Lima berdasarkan Teknik Kategorisasi dari Departemen Pendidikan Nasional yang dinyatakan sebagai berikut :

\section{Tabel 3.1 Kategorisasi Skala Lima}

\begin{tabular}{lll} 
No & Nilai & Kriteria \\
\hline $\mathbf{1}$ & $90-100$ & Sangat tinggi \\
$\mathbf{2}$ & $80-89$ & Tinggi \\
$\mathbf{3}$ & $65-79$ & Sedang \\
$\mathbf{4}$ & $55-64$ & Rendah \\
$\mathbf{5}$ & $00-54$ & Sangat Rendah \\
\hline
\end{tabular}

Sedangkan analisis kualitatif dilaksanakan sesuai dengan kecenderungan yang terjadi pada setiap siklus dengan melakukan penilaian secara verbal ( aktivitas yang teramati ) yaitu berupa kehadiran, perhatian, keaktifan dan hal-hal yang mendukung pembelajaran.

Penelitian dikatakan berhasil jika :

1. Nilai rata-rata kelas siswa mencapai Kriteria Katuntasan Minimal (KKM) yang ditentukan sekolah yaitu $\geq 65$

2. Persentase banyaknya siswa yang memperoleh nilai diatas Kriteria Ketuntasan Minimal $(\mathrm{KKM}) \geq 75 \%$ dan

3. Sikap siswa yang menunjukkan perubahan yang lebih baik dalam pembelajaran.

\section{Hasil dan Pembahasan}

\subsection{Hasil Penelitian}

\subsubsection{Hasil Tiap Siklus}

Analisis dilakukan untuk mendeskripsikan karakteristik responden penelitian untuk masing-masing siklus penelitian. Berdasarkan jenis data yang dikumpulkan, maka dilakukan 2 (dua) macam analisis yaitu analisis kuantitatif dan analisis kualitatif.

1. Analisis Kuantitatif

Setelah selesai melaksanakan penelitian tindaan dengan menggunakan model pembelajaran Cooperative Learning Tipe STAD dengan Pendekatan Scientific dalam penyampaian materi yang terdiri dari dua siklus, maka hasil yang diperoleh sebagai berikut: 
Jurnal Pendidikan; Vol. 7, No. 1, Januari 2019 p-ISSN: 2337-7607; e-ISSN : 2337-7593

a. Hasil Tes Siklus I

Analisis skor hasil tes siklus I dari hasil belajar matematika siswa kelas X Akutansi SMK Muhammadiyah Sorong dengan menggunakan Model Pemebelajaran Cooperative Learning Tipe STAD dengan Pendekatan Scientific disajikan dalam tabel berikut.

Tabel 4.1 Statistik Nilai Tes Hasil Siklus I

\begin{tabular}{lcc}
\multicolumn{1}{c}{ Statistik } & Nilai Statistik \\
\cline { 1 - 1 } Subjek & & 15 \\
Nilai ideal & & 100 \\
Nilai tertinggi & & 92 \\
Nilai terendah & & 22 \\
Rata-rata Nilai & & 59.44
\end{tabular}

Dari tabel 4.1, menunjukkan bahwa nilai rata-rata hasil belajar siswa setelah diadakan model pembelajaran dengan menerapkan model Pembelajaran Cooperative Learning Tipe STAD dengan Pendekatan Scientific adalah 59,44. Sedangkan secara individual, nilai yang dicapai responden tersebar dari nilai minimum 22 sampai dengan nilai maksimum 92 atau dalam rentang nilai 70. Ini menunjukkan bahwa hasil belajar pada Siklus I pada siswa kelas Siswa Kelas X Akutansi SMK Muhammadiyah Aimas cukup bervariasi dari hasil belajar sangat rendah sampai dengan hasil belajar sangat tinggi.

Jika nilai siswa dikelompokkan ke dalam lima kategori, maka diperoleh distribusi frekuensi nilai seperti pada tabel berikut:

\section{Tabel 4.2 Distribusi Frekuensi dan Persentase Skor Tes Hasil Belajar Siklus I}

\begin{tabular}{|c|c|c|c|c|}
\hline No & Nilai & Kategori & Frekuensi & Persentase $(\%)$ \\
\hline 1 & $0-54$ & Sangat Rendah & 3 & 20 \\
\hline 2 & $55-64$ & Rendah & 6 & 40 \\
\hline 3 & $65-79$ & Sedang & 2 & 13.33 \\
\hline 4 & $80-89$ & Tinggi & 3 & 20 \\
\hline 5 & $90-100$ & Sangat Tinggi & 1 & 6.67 \\
\hline \multicolumn{3}{|c|}{ Jumlah } & 15 & 100 \\
\hline
\end{tabular}

Setelah digunakan kategorisasi pada tabel 4.2 terlihat bahwa dari 15 siswa yang dijadikan subjek penelitian, maka terdapat 3 siswa (20\%) yang berada pada kategori sangat rendah, 6 siswa (40 \%) yang berada pada kategori rendah, 2 siswa $(13,33 \%)$ berada pada kategori sedang, 3 siswa $(20 \%)$ berada pada kategori tinggi dan 1 siswa $(6,67 \%)$ berada pada kategori sangat tinggi.

Nilai rata-rata hasil belajar matematika 59,44 yaitu berada pada interval $55-64$. Hal ini menunjukkan bahwa hasil belajar siswa setelah diadakan pembelajaran dengan menerapkan model pembelajaran dengan menerapkan model Pembelajaran Cooperative Learning Tipe STAD dengan Pendekatan Scientific berada dalam kategori yang pada umumnya masih rendah. 
Jika hasil belajar siswa pada Siklus I dianalisis, maka persentase ketuntasan belajar siswa dapat dilihat pada tabel 4.4 berikut ini :

Tabel 4.3 Deskripsi Ketuntasan Belajar Siswa Siklus I

\begin{tabular}{|c|c|c|c|c|}
\hline No & $\underline{\text { Nilai }}$ & $\underline{\text { Kategori }}$ & Frekuensi & $\underline{\text { Persentase }}$ \\
\hline 1 & $0-64$ & Tidak Tuntas & 9 & 60 \\
\hline 2 & $\underline{65-100}$ & $\underline{\text { Tuntas }}$ & $\underline{6}$ & 40 \\
\hline
\end{tabular}

Dari tabel di atas, nampak bahwa jumlah siswa yang tuntas belajar sebanyak 6 siswa ( $40 \%$ ) dan yang tidak tuntas belajar sebanyak 9 siswa (60\%). Ini menujukan bahwa siklus I masih perlu perbaikan lagi sehingga peneliti melanjutkan kegiatan pembelajaran pada siklus II.

b. Hasil Tes Siklus II

Analisis secara kuantitatif hasil belajar siswa berdasarkan hasil Siklus II Siswa Kelas X Akutansi SMK Muhammadiyah Aimas, dapat dilihat pada tabel berikut :

\section{Tabel 4.4 Statistik Nilai Tes Hasil Belajar Siklus II}

\begin{tabular}{lcc}
\hline \multicolumn{1}{c}{ Statistik } & & Nilai Statistik \\
\cline { 1 - 1 } Subjek & 15 \\
Nilai ideal & 100 \\
Nilai tertinggi & & 100 \\
Nilai terendah & 56 \\
Rata-rata Nilai & & 85.17
\end{tabular}

Dari tabel 4.4 menunjukkan bahwa nilai rata-rata hasil belajar siswa setelah diadakan tindakan lanjutan yaitu 85,17. Sedangkan secara individual, nilai yang dicapai responden tersebar dari nilai minimum 56 sampai dengan nilai maksimum 100. Ini menunjukkan bahwa hasil belajar Siklus II pada Siswa Kelas X Akutansi SMK Muhammadiyah Aimas cukup bervariasi dari hasil belajar rendah sampai dengan hasil belajar sangat tinggi.

Jika nilai siswa dikelompokkan ke dalam lima kategori, maka diperoleh distribusi frekuensi nilai seperti pada tabel berikut:

Tabel 4.5 Distribusi Frekuensi dan Persentase Skor Tes Hasil Belajar Siklus II

\begin{tabular}{cclcr}
\hline No & Nilai & \multicolumn{1}{c}{ Kategori } & Frekuensi & Persentase (\%) \\
\hline 1 & $0-54$ & Sangat Rendah & 0 & 0 \\
2 & $55-64$ & Rendah & 1 & 6.67 \\
3 & $65-79$ & Sedang & 3 & 20 \\
4 & $80-89$ & Tinggi & 7 & 46.67 \\
5 & $90-100$ & Sangat Tinggi & 4 & 26.66 \\
\hline \multicolumn{5}{c}{ Jumlah } \\
\hline
\end{tabular}

Setelah digunakan kategorisasi pada tabel 4.5 terlihat bahwa dari 15 siswa yang dijadikan subjek penelitian, maka tak ada siswa $(0 \%)$ yang berada pada kategori sangat 
rendah, 1 siswa (6.67\%) yang berada pada kategori rendah, 3 siswa (20\%) berada pada kategori sedang, 7 siswa $(46,67 \%)$ berada pada kategori tinggi dan 4 siswa $(26.66 \%)$ berada pada kategori sangat tinggi.

Nilai rata-rata hasil belajar matematika 85,17 yaitu berada pada interval $80-89$. Hal ini menunjukkan bahwa hasil belajar siswa setelah diadakan pembelajaran dengan menggunakan model Pembelajaran Cooperative Learning Tipe STAD dengan Pendekatan Scientific berada dalam kategori yang pada umumnya tinggi.

Jika hasil belajar siswa pada Siklus II dianalisis, maka persentase ketuntasan belajar siswa dapat dilihat pada tabel 4.6 berikut ini :

Tabel 4.6 Deskripsi Ketuntasan Belajar Siswa Siklus II

\begin{tabular}{lcccr}
\hline No & Skor & Kategori & Frekuensi & Persentase \\
\hline 1. & $0-64$ & Tidak Tuntas & 1 & $6.67 \%$ \\
2. & $65-100$ & Tuntas & 14 & $93.33 \%$ \\
\hline
\end{tabular}

Dari tabel di atas, nampak bahwa jumlah siswa yang tuntas belajar sebanyak 14 siswa $(93,33 \%)$ dan yang tidak tuntas belajar sebanyak 1 siswa $(6,67 \%)$.

Untuk melihat secara langsung peningkatan hasil belajar matematika Siswa Kelas X Akutansi SMK Muhammadiyah Aimas pada setiap siklus dapat dilihat pada tabel berikut ini :

Tabel 4.7 Statistik Skor Hasil Belajar Matematika Siklus I dan Siklus II

\begin{tabular}{llccccc}
\hline $\begin{array}{c}\text { N } \\
\text { o }\end{array}$ & $\begin{array}{c}\text { Siklus } \\
\text { Penelitian }\end{array}$ & $\begin{array}{c}\text { Sub } \\
\text { yek }\end{array}$ & $\begin{array}{c}\text { Maksi } \\
\text { mum }\end{array}$ & $\begin{array}{c}\text { Mini- } \\
\text { mum }\end{array}$ & Mean & $\begin{array}{c}\text { Ketuntasan } \\
\text { Belajar }\end{array}$ \\
\hline 1. & Siklus I & 15 & 92 & 22 & 59.44 & $40 \%$ \\
2. & Siklus II & 15 & 100 & 56 & 85.17 & $93,33 \%$ \\
\hline
\end{tabular}

Dari data di atas, dapat dilihat bahwa nilai rata-rata perolehan siswa dari tes Siklus I sampai tes Siklus II mengalami peningkatan. 
Jurnal Pendidikan; Vol. 7, No. 1, Januari 2019 p-ISSN: 2337-7607; e-ISSN : 2337-7593

2. Analisis Kualitatif

a. Siklus I

Tabel 4.8 Persentase hasil observasi siklus I

\begin{tabular}{|c|c|c|c|c|c|}
\hline Perte- & Kehadiran & $\begin{array}{l}\text { Memper- } \\
\text { hatikan }\end{array}$ & $\begin{array}{l}\text { Menjawab } \\
\text { Pertanyaan }\end{array}$ & $\begin{array}{c}\text { Menjawab } \\
\text { dengan }\end{array}$ & $\begin{array}{c}\text { Menanggapi } \\
\text { jawaban } \\
\text { kelompok }\end{array}$ \\
\hline & & & & Benar & lain \\
\hline
\end{tabular}

\begin{tabular}{ccccccccccc} 
& $\mathrm{f}$ & $\%$ & $\mathrm{f}$ & $\%$ & $\mathrm{f}$ & $\%$ & $\mathrm{f}$ & $\%$ & $\mathrm{f}$ & $\%$ \\
\hline 1 & 11 & 74 & 11 & 74 & 10 & 67 & 9 & 60 & 10 & 67 \\
2 & 13 & 86 & 11 & 74 & 11 & 74 & 9 & 60 & 11 & 74 \\
3 & 15 & 100 & 12 & 80 & 11 & 74 & 11 & 74 & 10 & 67 \\
4 & 15 & 100 & 12 & 80 & 11 & 74 & 13 & 86 & 13 & 86 \\
\hline \multicolumn{2}{l}{ Rata-Rata } & 90 & & 77 & & 74.75 & & 70 & & 73.5 \\
\hline
\end{tabular}

Berdasarkan table 4.8 diatas, dapat dilihat beberapa perubahan sikap siswa yaitu :

a. Siswa yang yang hadir pada pertemuan ke-1 yakni 11 siswa atau $74 \%$ dan pada pertemuan ke-4 meningkat menjadi 15 siswa $100 \%$.

b. Siswa yang memperhatikan penekanan inti suatu materi pada pertemuan ke-1 hanya 11 siswa atau $74 \%$ dan pada pertemuan ke-4 meningkat menjadi 12 siswa $80 \%$.

c. Demikian halnya siswa yang menjawab pertanyaan pada pertemuan ke-1 terdapat 10 siswa atau $67 \%$ dan pada pertemuan ke-4 meningkat menjadi 11 siswa atau $74 \%$.

d. Siswa yang menjawab dengan benar pada pertemuan ke-1 sebanyak 9 siswa atau 60\% dan pada akhir siklus menjadi 13 siswa atau 86\%.

e. Jumlah siswa yang menanggapi jawaban kelompok lain meningkat, yaitu pada pertemuan pertama sebanyak 10 siswa atau $67 \%$ siswa dan pada pertemuan ke-4 menjadi 13 siswa atau $86 \%$ siswa yang menanggapi jawaban dari kelompok lain. 
Jurnal Pendidikan; Vol. 7, No. 1, Januari 2019 p-ISSN: 2337-7607; e-ISSN : 2337-7593

b. Siklus II

Tabel 4.9 Persentase hasil observasi siklus II

\begin{tabular}{ccccccccccc}
\multirow{2}{*}{$\begin{array}{c}\text { Perte- } \\
\text { muan }\end{array}$} & Kehadiran & $\begin{array}{c}\text { Memper- } \\
\text { hatikan } \\
\text { Materi }\end{array}$ & $\begin{array}{c}\text { Menjawab } \\
\text { Pertanyaan }\end{array}$ & $\begin{array}{c}\text { Menjawab } \\
\text { dengan } \\
\text { Benar }\end{array}$ & $\begin{array}{c}\text { Menanggapi } \\
\text { jawaban } \\
\text { kelompok } \\
\text { lain }\end{array}$ \\
\cline { 2 - 11 } & $\mathrm{f}$ & $\%$ & $\mathrm{f}$ & $\%$ & $\mathrm{f}$ & $\%$ & $\mathrm{f}$ & $\%$ & $\mathrm{f}$ & $\%$ \\
\hline 1 & 13 & 86 & 13 & 86 & 12 & 80 & 11 & 74 & 11 & 74 \\
2 & 15 & 100 & 14 & 94 & 12 & 80 & 11 & 74 & 12 & 80 \\
3 & 15 & 100 & 14 & 94 & 13 & 86 & 13 & 86 & 13 & 86 \\
4 & 15 & 100 & 14 & 94 & 13 & 86 & 13 & 86 & 13 & 86 \\
\hline Rata-Rata & 96.5 & & 92 & & 83 & & 80 & & 81,5 \\
\hline
\end{tabular}

Berdasarkan table 4.9 diatas, dapat dilihat beberapa perubahan sikap siswa yaitu :

a Siswa yang hadir pada pelaksanaan tindakan Siklus II tidak jauh berbeda dengan Siklus I, sesekali terdapat 1 sampai 3 siswa yang tidak hadir dengan alasan sakit, ijin atau tanpa alasan sama sekali.

b. Siswa yang memperhatikan penekanan inti suatu materi pada pertemuan ke-1 adalah 13 siswa atau $86 \%$ meningkat menjadi 14 siswa atau $94 \%$ pada pertemuan ke-4.

c. Motivasi siswa semakin meningkat. Ini terlihat dari banyaknya siswa yang menjawab pertanyaan yaitu pada pertemuan ke-1 terdapat 12 siswa atau $80 \%$ meningkat menjadi 13 siswa atau 86\% pada pertemuan ke-4.. Hal ini menandakan bahwa motivasi siswa untuk mengikuti pembelajaran semakin meningkat.

d. Pemahaman siswa semakin baik. Ini terihat dengan terdapat 11 siswa atau $74 \%$ yang menjawab dengan benar pada pertemuan ke-1 meningkat menjadi 13 siswa atau $86 \%$ pada pertemuan ke-4.

e. Siswa yang menanggapi jawaban temannya pada pertemuan ke-1 adalah 11 siswa atau $74 \%$ meningkat menjadi 13 siswa atau $86 \%$ pada pertemuan ke- 4 ..

\subsection{Pembahasan}

\section{Hasil Belajar Matematika}

Berdasarkan hasil analisis data yang telah diuraikan di atas, maka secara deskriptif hasil penelitian tindakan mengungkapkan adanya peningkatan hasil belajar matematika Siswa Kelas X Akutansi SMK Muhammadiyah Aimas melalui model Pembelajaran Cooperative Learning Tipe STAD dengan Pendekatan Scientific

Hasil analisis deskriptif pada tabel 4.2 untuk siklus I menunjukkan bahwa hasil belajar Siswa Kelas X Akutansi SMK Muhammadiyah Aimas masih menyebar. Dari 15 siswa, 3 siswa (20\%) memperoleh skor sangat rendah, 6 siswa (40\%) memperoleh skor tergolong rendah, 2 siswa (13,33\%) memperoleh skor tergolong sedang, 3 siswa (20\%) memperoleh skor tergolong tinggi dan 1 siswa $(6,67 \%)$ 
Jurnal Pendidikan; Vol. 7, No. 1, Januari 2019 p-ISSN: 2337-7607; e-ISSN : 2337-7593

memperoleh skor tergolong sangat tinggi. Berdasarkan tabel 4.3 bahwa persentase siswa yang tidak tuntas belajar sebesar $60 \%$ sedangkan yang tuntas sebesar $40 \%$.

Selanjutnya hasil analisis deskriptif pada tabel 4.5 untuk siklus II menunjukkan bahwa hasil belajar matematika Kelas X Akutansi SMK Muhammadiyah Aimas mengalami perubahan. Dari 15 siswa, tak ada siswa (0\%) memperoleh skor sangat rendah, 1 siswa $(6,67 \%)$ memperoleh skor tergolong rendah, 3 siswa (20\%) memperoleh skor tergolong sedang, 7 siswa (46,67 \%) memperoleh skor tergolong tinggi dan 4 siswa $(26,66 \%)$ memperoleh skor tergolong sangat tinggi.

Berdasarkan tabel 4.6, Pada Siklus II jumlah siswa yang tuntas belajar sebanyak 14 siswa atau 973,33 \% siswa dan yang tidak tuntas belajar sebanyak 1 siswa atau 6,67 \% siswa. Sedangkan hasil statistik skor pada tabel 4.7 menunjukkan meningkatnya skor rata-rata yang dicapai siswa dari 52,72 pada siklus I menjadi 85,17 pada siklus II. Berdasarkan hal tersebut, maka jelas bahwa hasil belajar matematika pada Siklus II lebih meningkat dibandingkan Siklus I

\section{Hasil Observasi Perubahan Sikap Siswa Tiap Siklus}

Tabel 4.12 Data Hasil Observasi Pada Siklus I dan Siklus II

\begin{tabular}{ccccccc}
\hline & & \multicolumn{4}{c}{ Banyak siswa dan Aspek yang diamati } \\
\cline { 3 - 6 } No & Siklus & Kehadiran & Memperhatikan & menjawab & $\begin{array}{c}\text { Menjawab } \\
\text { dengan benar }\end{array}$ & Menanggapi \\
\hline 1 & I & $90 \%$ & $77 \%$ & $74.75 \%$ & $70 \%$ & $73.5 \%$ \\
2 & II & $96.5 \%$ & $92 \%$ & $83 \%$ & $80 \%$ & $81.5 \%$ \\
\hline
\end{tabular}

Dari awal penelitian berlangsung hingga berakhirnya Siklus, tercatat beberapa perubahan yang terjadi pada siswa. Hal-hal yang dimaksud antara lain :

1) Siswa yang hadir pada saat pelaksanaan tindakan pada saat Siklus I sebesar $90 \%$ dan pada Siklus II sebesar 96,5\%. Siswa yang tidak hadir dengan alasan sakit, izin atau tanpa alasan sama sekali.

2) Siswa yang memperhatikan penekanan inti suatu materi meningkat. Pada Siklus I sebesar $77 \%$ dan pada Siklus II sebesar $92 \%$.

3) Siswa yang menjawab pertanyaan pada saat pengembangan konsep meningkat, Pada Siklus I sebesar 74,75\% dan pada Siklus II sebesar $83 \%$.

4) Siswa yang menjawab dengan benar juga meningkat. Pada Siklus I sebesar $70 \%$ dan pada Siklus II sebesar $80 \%$.

5) Siswa yang menanggapi jawaban dari siswa lain juga meningkat, Pada Siklus I sebesar 73,5\% dan pada Siklus II sebesar $81,5 \%$. Ini menunjukkan bahwa motivasi siswa untuk mengikuti pembelajaran sudah meningkat.

Dengan demikian penerapan model Pembelajaran Cooperative Learning Tipe STAD dengan Pendekatan Scientific dapat membuat siswa lebih bersemangat dan termotivasi untuk lebih aktif dalam pembelajaran sehingga hasil belajar matematika siswa meningkat.

\section{Kesimpulan dan Saran}

\subsection{Kesimpulan}

Berdasarkan hasil data dan pembahasan skor rata-rata hasil belajar matematika siswa Kelas X Akutansi SMK Muhammadiyah Aimas setelah diberi tindakan pada siklus I adalah 59,44 dari skor tertinggi yang mungkin dicapai yaitu 100 atau berada pada kategori rendah. Selanjutnya skor rata-rata 
Jurnal Pendidikan; Vol. 7, No. 1, Januari 2019 p-ISSN: 2337-7607; e-ISSN : 2337-7593

hasil belajar matematika Kelas X Akutansi SMK Muhammadiyah Aimas setelah diberi tindakan pada siklus II adalah 85,17 dari skor tertinggi yang mungkin dicapai yaitu 100 atau berada pada kategori tinggi, maka dapat ditarik kesimpulan penerapan pembelajaran dengan menggunakan Pembelajaran Cooperative Learning Tipe STAD dengan Pendekatan Scientific dapat meningkatkan hasil belajar Kelas X Akutansi SMK Muhammadiyah Aimas yang indikatornya berupa peningkatan skor rata-rata hasil belajar matematika siswa dari kategori rendah pada siklus I sebesar 59,44 menjadi 85,17 pada siklus II yang berada pada kategori tinggi.

\subsection{Saran}

1. Untuk dapat meningkatkan hasil belajar siswa maka dapat diterapkan Pembelajaran Cooperative Learning Tipe STAD dengan Pendekatan Scientific yang dimaksudkan agar siswa lebih cepat menyerap materi pelajaran karena mereka bisa saling membantu di dalam kelompoknya, siswa lebih antusias dalam pembelajaran karena model pembelajaran yang menarik, menyenangkan dan bermakna bagi siswa.

2. Disarankan guru-guru di sekolah dapat menguasai beberapa metode dan model pembelajaran agar dalam memaparkan materi pembelajaran lebih bervariasi dan efektif..

\section{Daftar Pustaka}

Akhsin, Nur, dan Astuti, Anna Yuni. 2007. Matematika Realistik :Kelas VII untuk SMP dan MTs. Intan Pariwara : Klaten.

Arikunto, Suharsimi. 2011. Penelitian Tindakan 2010. Aditya Media :Yogyakarta.

Fitrianingrum, Anita. 2011. Efektivitas Pembelajaran Kooperatif Tipe Jingsaw dan Make A Match Terhadap Hasil Belajar Matematika Siswa Kelas VIII SMP Mumahammadiyah Imogiri. Skripsi. Jurusan Pendidikan Matematika FST UINSK : Yogyakarta. (Tidak dipublikasikan)

Haryono, Ari Dwi dan Aries, Erna Febru, 2012. Penelitian Tindakan Kelas : Teori dan Aplikasinya. Aditya Media Publishing : Yogyakarta.

Huda, Miftahul. 2012. Cooperative Learning. Pustaka Belajar : Yogyakarta.

Muzaki, lubis. Penerapan Pembelajaran Cooperative Learning dengan Teknik Make A Matc, online. diakses pada 6 Desember 2012.

Nasir, Umar. 1997. Korelasi Motivasi Belajar Matematika Dengan Prestasi Belajar Matematika Siswa Kelas II Sekolah Pertanian Pembangunan Daerah Jayapura Tahun Ajaran 1996/1997. Skripsi. Jurusan Pendidikan Matematika FKIP UNCEN: Jayapura. (Tidak dipublikasikan)

Nyataraharja. 2007. Peningkatan Hasil Belajar Matematika Melalui

Pembelajaran Kontekstual Pada Siswa Kelas IX A SMP Negeri 4 Sorong. Skripsi. Jurusan Matematika FMIPA UNM : Makassar. (Tidak dipublikasikan)

Riyanto, Yatim. 2010. Paradigma Baru Pembelajaran. Kencana Prenada Media Group : Jakarta.

Simple English Course.Penerapan Pendekatan Pembelajaran Kooperatif Tipe Make Macth dapat Meningkatkan Prestasi Belajar IPS Siswa Kelas IV SDN 1 Sukarara 2010/2011,online. diakses pada 14 Februari 2013.

Sucipto.2009. Peningkatan Hasil Beajar Matematika Melalui Pembelajaran Kontekstual Pada Siswa Kelas VIII SMP IT Nurul Yaqin Kabupaten Sorong.Skripsi. Jurusan Pendidikan Matematika FKIP Universitas Al -

Amin (UNAMIN) Muhammadiyah Sorong: Sorong. (Tidak dipublikasikan)

Sudjana, Nana. 2011. Penilaian Hasil Proses Belajar Mengajar. PT Remaja Rosdakarya : Bandung.

Suhardjono, dkk. 2010. Penelitian Tindakan Kelas. PT Bumi Aksara : Jakarta.

Sumarini. 2001. Meningkatkan Hasil Belajar Matematika Pada Siswa Kelas 1 
Jurnal Pendidikan; Vol. 7, No. 1, Januari 2019 p-ISSN: 2337-7607; e-ISSN : 2337-7593

SLTP Kartika VII-7 Makassar Melalui Pemberian Bimbingan Ekstra.

Skripsi. FMIPA UNM: Makassar. (Tidak dipublikasikan)

Suprijono, Agus. 2012. Cooperative Learning. Pustaka Belajar : Yogyakarta.

Trisnawati, Nika Fetria. 2011. Meningkatkan Hasil Belajar Matematika Siswa dengan Menggunakan Model Pembelajaran Kooperatif Tipe Think-Pair-Share (TPS) Pada Siswa VB SD Muhammadiyah I Sorong. Skripsi.

Jurusan Pendidikan Matematika FKIP UMS: Sorong (Tidak dipublikasikan) 